\title{
Prognostic role of pretreatment thrombocytosis on survival in patients with cervical cancer: a systematic review and meta-analysis
}

\author{
Weijuan Cao ${ }^{1}$, Xiaomin Yao ${ }^{1}$, Danwei Cen ${ }^{1}$, Yajun Zhi', Ningwei Zhu ${ }^{1}$ and Liyong $\mathrm{Xu}^{2^{*}}$
}

\begin{abstract}
Background: This meta-analysis summarized the prognostic role of an elevated platelet count before treatment on survival outcomes in patients with cervical cancer.

Methods: The PubMed, Embase, and Cochrane library electronic databases were systematically searched for studies reporting the effect estimates with $95 \%$ confidence intervals (Cls) of pretreatment thrombocytosis on survival from the database inceptions to December 2018. The pooled hazard ratios (HRs) with 95\% Cls for overall survival (OS), progression-free survival (PFS), and recurrence-free survival (RFS) were calculated using random-effects models.

Results: Nineteen retrospective studies that recruited 6521 patients with cervical cancer were eligible for this study. The summary results indicated that an elevated platelet count was significantly associated with a poor OS (HR 1.50; 95\% Cl 1.19-1.88; $P=0.001$ ), PFS (HR 1.33; 95\% Cl 1.07-1.64; $P=0.010)$, and RFS (HR 1.66; 95\% Cl 1.20-2.28; $P=0.002)$. Sensitivity analysis indicated that the pooled PFS was variable after sequential exclusion of individual studies. The predictive value of pretreatment thrombocytosis on OS differed according to the publication year $(P=$ $0.039)$, country $(P=0.013)$, and sample size $(P=0.029)$, and the role of pretreatment thrombocytosis on PFS could be affected by the study quality $(P=0.046)$.

Conclusion: The findings of this study indicated that an elevated platelet count before treatment was associated with poor OS, PFS, and RFS. These results require further verification in large-scale prospective studies.
\end{abstract}

Keywords: Meta-analysis, Prognosis, Thrombocythemia, Cervical cancer

\section{Background}

Cervical cancer has the second highest incidence and the fourth leading mortality due to cancer in women worldwide, with a reported 527,000 new cases and 265, 700 deaths annually [1]. Nearly $85 \%$ of cervical cancer cases occur in developing countries and women aged 40-45 years have the highest disease incidence [2]. Epidemiologic studies have identified several factors that could affect the progression of cervical cancer, including human papillomavirus, oral contraceptives, sexual promiscuity, and smoking [3-6]. Currently, radical hysterectomy

\footnotetext{
*Correspondence: 1529228295@qq.com

${ }^{2}$ Zhejiang Pharmaceutical College, No. 888, East Section of Yinxian Avenue, Higher Education Park, Ningbo 315100, Zhejiang Province, China Full list of author information is available at the end of the article
}

with pelvic lymph node dissection is widely used for the treatment of early-stage cervical cancer, although recurrences occur in nearly $25 \%$ of patients $[7,8]$. Concurrent chemoradiotherapy is the standard treatment strategy in patients with invasive cervical cancer, with a risk of recurrence ranging from 10 to $20 \%$ in patients with stage $\mathrm{Ib}$ to IIa disease and 50 to $70 \%$ in patients with stage IIb to IVa disease [9]. Therefore, effective prognostic factors should be explored to predict survival outcomes in patients with cervical cancer.

The incidence of thrombocytosis ranged from 4 to $55 \%$ of patients with malignant tumors at initial diagnosis and during the course of the disease, which may be due to various cytokines and growth factors $[10,11]$. Inflammatory responses caused by cancer might play an

(C) The Author(s). 2019 Open Access This article is distributed under the terms of the Creative Commons Attribution 4.0 International License (http://creativecommons.org/licenses/by/4.0/), which permits unrestricted use, distribution, and 
important role in tumor development including cancer initiation, promotion, malignancy conversion, invasion, and metastasis at various stages [12]. Numerous studies have demonstrated the prognostic role of inflammatory biomarkers on survival in patients with various diseases, including platelet count, anemia, and red cell distribution width [13-15]. Moreover, previous studies have indicated that tumor-derived interleukin- 6 could stimulate thrombopoiesis, leading to thrombocytosis and tumor progression in patients with ovarian cancer [16]. However, the prognostic role of platelet count in patients with cervical cancer remains controversial. As the measurement of platelet count is economical and easily accessible in clinical practice, we conducted a systematic review and meta-analysis to verify the prognostic value of thrombocytosis on survival outcomes in patients with cervical cancer to identify an additional effective biomarker.

\section{Methods}

\section{Data sources, search strategy, and selection criteria}

The current meta-analysis was conducted and reported following the Preferred Reporting Items for Systematic Reviews and Meta-Analysis Statement issued in 2009 [17]. We searched PubMed, Embase, and the Cochrane library for studies that investigated the prognostic role of thrombocytosis on survival outcomes in patients with cervical cancer from the inception of the databases up to December 2018 using the following search terms as medical subject headings and free words: ("thrombocytosis" or "thrombocythemia" or "platelet count" or "platelet") AND ("cervical cancer" or "cervical tumor" or "cervical neoplasm" or "cervical carcinoma") AND ("prognosis" or "outcome" or "survival" or "mortality" or "recurrence" or "progression" or "metastasis"). After the selection of potentially eligible studies based on the inclusion criteria, manual searches of the reference lists of the retrieved studies were also conducted to identify additional studies for consideration.

The literature search and study selection were conducted independently by two authors and a third author made the final decision if cases of disagreement. A study was included if it met the following inclusion criteria: (1) study design: both prospective or retrospective studies were included; (2) patients: patients in retrieved studies diagnosed with cervical cancer, irrespective of disease stages; (3) exposure: platelet count or thrombocytosis were measured before treatment; (4) control: the platelet count before treatment was normal in the control group; and (5) outcomes: the study should report at least one of following outcomes: overall survival (OS), progressionfree survival (PFS), and recurrence-free survival (RFS). Study designed as review, reported other hematological markers and other outcomes were excluded.

\section{Data collection and quality assessment}

The collected data included first authors' surname, publication year, country, study design, sample size, mean age, disease stages, treatment strategy, platelet count cutoff, adjusted factors, and reported outcomes. Study quality was evaluated using the Newcastle-Ottawa Scale (NOS), which is the most commonly used tool for evaluating the quality of observational studies in meta-analyses [18]. The NOS system is based on selection (4 items), comparability (1 item), and outcome (3 items), with a star system ranging from 0 to 9 for quality assessment. The data collection and quality assessment were carried out by two authors, with inconsistencies resolved by an additional author referring to the original article.

\section{Statistical analysis}

The pooled hazard ratios (HRs) with 95\% confidence intervals (CIs) for OS, PFS, and RFS were calculated using the adjusted or crude HRs and 95\% CIs reported in individual studies. All pooled results were calculated using a random-effects model, allowing for the true underlying effect to vary among included studies $[19,20]$. The heterogeneity across the included studies was assessed as proposed by Higgins, which provides the percentage of total variation among included studies [21]. Moreover, $P$ values for $Q$ statistics were calculated, with $P<0.100$ indicating significant heterogeneity [22]. Sensitivity analysis was conducted for OS, PFS, and RFS to evaluate the impacts of single studies on the overall analysis [23]. Subgroup analyses were also performed based on publication year, country, sample size, mean age, treatment strategy, cutoff value, adjusted or not, and study quality. $P$ values between

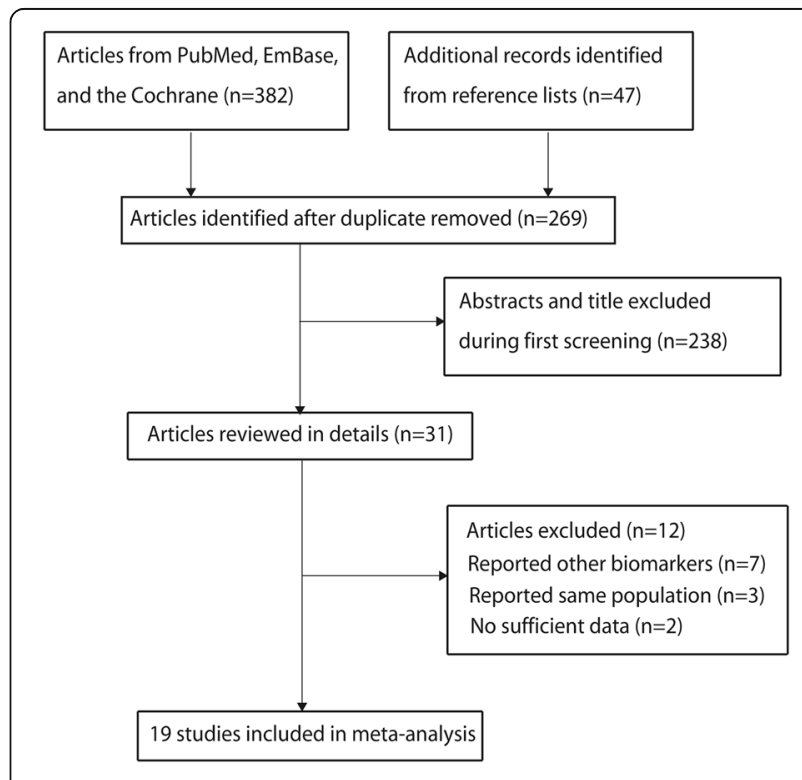

Fig. 1 Flow diagram of the literature search and study selection process 
Table 1 Baseline characteristics of studies included in the meta-analysis

\begin{tabular}{|c|c|c|c|c|c|c|c|c|c|c|c|}
\hline Study & $\begin{array}{l}\text { Publication } \\
\text { year }\end{array}$ & Country & Study design & $\begin{array}{l}\text { Sample } \\
\text { size }\end{array}$ & $\begin{array}{l}\text { Mean age } \\
\text { (years) }\end{array}$ & $\begin{array}{l}\text { Disease } \\
\text { stages }\end{array}$ & Treatment strategy & $\begin{array}{l}\text { Cutoff } \\
\text { value }\end{array}$ & $\begin{array}{l}\text { Adjusted } \\
\text { or not }\end{array}$ & $\begin{array}{l}\text { Reported } \\
\text { outcomes }\end{array}$ & $\begin{array}{l}\text { NOS } \\
\text { scale }\end{array}$ \\
\hline $\begin{array}{l}\text { Hernandez } \\
\text { et al. [33] }\end{array}$ & 1992 & USA & Retrospective & 113 & 59.2 & I-IV & Radiation & 400 & Not & OS & 5 \\
\hline $\begin{array}{l}\text { Lopes et al. } \\
\text { [37] }\end{array}$ & 1994 & England & Retrospective & 643 & 45.5 & Ib-IV & Surgery or radiation & 400 & Not & OS & 7 \\
\hline $\begin{array}{l}\text { Hernandez } \\
\text { et al. [32] }\end{array}$ & 1994 & USA & Retrospective & 623 & NS & $\mathrm{lb}$ & Surgery & 400 & Not & OS, PFS & 7 \\
\hline $\begin{array}{l}\text { Rodriguez } \\
\text { et al. [40] }\end{array}$ & 1994 & USA & Retrospective & 219 & 40.0 & $\mathrm{lb}$ & Surgery & 300 & Not & OS & 5 \\
\hline $\begin{array}{l}\text { De Jonge } \\
\text { et al. [28] }\end{array}$ & 1999 & $\begin{array}{l}\text { South } \\
\text { Africa }\end{array}$ & Retrospective & 93 & NS & $\mathrm{lb}$ & Surgery & 400 & Yes & OS, RFS & 6 \\
\hline $\begin{array}{l}\text { Hernandez } \\
\text { et al. [31] }\end{array}$ & 2000 & USA & Retrospective & 291 & 49.8 & Ilb-IVa & Surgery or radiation & 400 & Yes & OS & 6 \\
\hline $\begin{array}{l}\text { Qiu et al. } \\
\text { [39] }\end{array}$ & 2010 & China & Retrospective & 318 & 43.0 & I-IV & NS & 400 & Not & OS & 6 \\
\hline $\begin{array}{l}\text { Gadducci } \\
\text { et al. [29] }\end{array}$ & 2010 & Italy & Retrospective & 46 & 47.0 & $|b-| \mid b$ & $\begin{array}{l}\text { Surgery or } \\
\text { chemotherapy }\end{array}$ & 272 & Not & OS, RFS & 6 \\
\hline $\begin{array}{l}\text { Gadducci } \\
\text { et al. [30] }\end{array}$ & 2010 & Italy & Retrospective & 140 & 47.0 & $|b-| \mid b$ & $\begin{array}{l}\text { Surgery or } \\
\text { chemotherapy }\end{array}$ & 272 & Not & OS, RFS & 6 \\
\hline $\begin{array}{l}\text { Wang et al. } \\
\text { [41] }\end{array}$ & 2012 & China & Retrospective & 111 & 42.0 & $|b-| \mid b$ & $\begin{array}{l}\text { Surgery or } \\
\text { chemotherapy }\end{array}$ & 266 & Not & OS, PFS & 5 \\
\hline $\begin{array}{l}\text { Biedka et al. } \\
\text { [27] }\end{array}$ & 2012 & Poland & Retrospective & 58 & NS & I-IV & Surgery or radiation & NS & Not & PFS & 5 \\
\hline $\begin{array}{l}\text { Zhao et al. } \\
\text { [44] }\end{array}$ & 2015 & China & Retrospective & 220 & NS & I-Ila & Surgery & 300 & Not & OS, RFS & 6 \\
\hline $\begin{array}{l}\text { Xiao et al. } \\
{[42]}\end{array}$ & 2015 & China & Retrospective & 238 & 52.0 & I-IV & $\begin{array}{l}\text { Radiation and } \\
\text { chemotherapy }\end{array}$ & 200 & Not & OS, PFS & 6 \\
\hline Li et al. [36] & 2015 & China & Retrospective & 380 & 51.0 & $|a-| l b$ & Surgery & 300 & Not & OS & 6 \\
\hline $\begin{array}{l}\text { Koulis et al. } \\
{[34]}\end{array}$ & 2017 & Canada & Retrospective & 257 & 50.0 & $\mathrm{Ib}-\mathrm{IV}$ & $\begin{array}{l}\text { Chemoradiotherapy } \\
\text { and surgery }\end{array}$ & 400 & $\begin{array}{l}\text { Yes (OS), } \\
\text { No (PFS) }\end{array}$ & OS, PFS & 7 \\
\hline $\begin{array}{l}\text { Kozasa et al. } \\
{[35]}\end{array}$ & 2017 & Japan & Retrospective & 684 & NS & I-IV & $\begin{array}{l}\text { Chemoradiotherapy } \\
\text { and surgery }\end{array}$ & 350 & Yes & OS, PFS & 7 \\
\hline $\begin{array}{l}\text { Zheng et al. } \\
\text { [45] }\end{array}$ & 2017 & China & Retrospective & 800 & 49.5 & la-lla & Surgery & 272 & Yes & OS, RFS & 7 \\
\hline $\begin{array}{l}\text { Nakamura } \\
\text { et al. [38] }\end{array}$ & 2018 & Japan & Retrospective & 98 & 65.0 & I-IV & $\begin{array}{l}\text { Radiation and } \\
\text { chemotherapy }\end{array}$ & 350 & Not & OS, PFS & 6 \\
\hline $\begin{array}{l}\text { Xu et al. } \\
{[43]}\end{array}$ & 2018 & China & Retrospective & 1189 & NS & la-lla & Surgery & 300 & Yes & PFS & 7 \\
\hline
\end{tabular}

subgroups were calculated using chi-square tests to explore the difference of the effect estimates between subgroups [24]. Publication biases for OS, PFS, and RFS were calculated using funnel plots, Egger [25], and Begg [26] test results. The $P$ values for all pooled results were twosided, and $P<0.05$ was considered statistically significant. All analyses were conducted using STATA (version 10.0; Stata Corporation, College Station, TX, USA).

\section{Results}

Literature search

A total of 382 records were identified in the initial search of the PubMed, EmBase, and Cochrane library electronic databases; of these, 160 duplicated and 238 irrelevant records were excluded. The remaining 31 studies were retrieved for full-text evaluations, and 12 studies were excluded for the following: reported other biomarkers $(n=7)$, reported on the same population $(n=3)$, and insufficient data $(n=2)$. No new eligible studies were obtained in the manual searches of the reference lists of the remaining studies. Finally, a total of 19 studies were included in the present study [27-45]. The flow diagram of the study inclusion is presented in Fig. 1.

\section{Study characteristics}

We identified a total of 19 retrospective studies including 6521 patients with cervical cancer. The baseline characteristics of included studies or patients are presented in Table 1. 


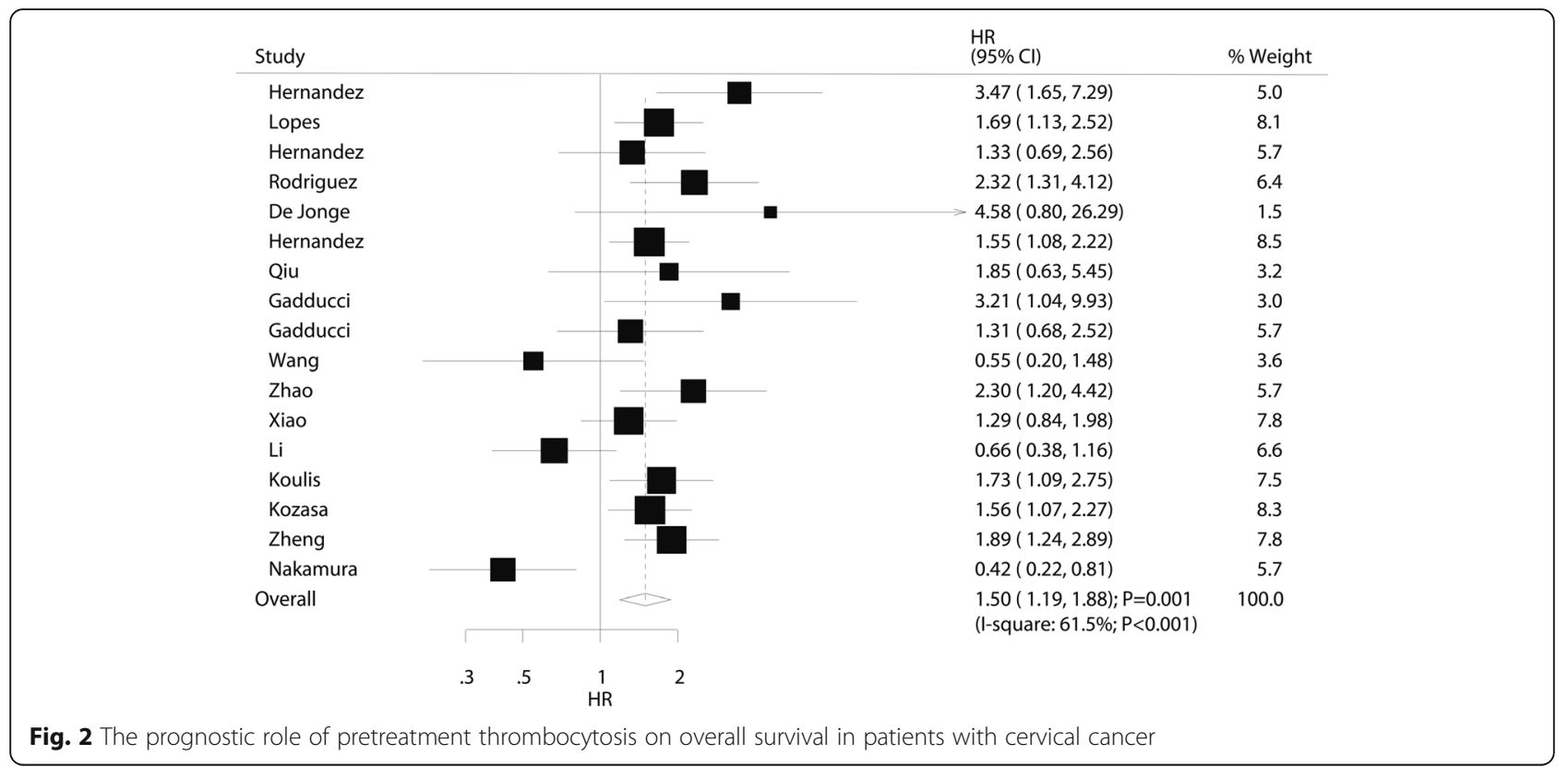

These studies were published in 1992-2018, and the sample sizes ranged from 46 to 1189 . The included studies were conducted in China $(n=7)$, the USA $(n=4)$, Japan $(n=2)$, Italy $(n=2)$, England $(n=1)$, South Africa $(n=1)$, Poland $(n=1)$, and Canada $(n=1)$. Ten of the studies included patients diagnosed at early stages, and the remaining nine studies included patients at all stages. The quality of the included studies is shown in the last column of Table 1. Six studies had seven stars, nine studies had six stars, and the remaining four studies had five stars.

\section{Overall survival}

The prognostic value of pretreatment thrombocytosis on OS was available in 17 studies. Overall, thrombocytosis before treatment was associated with a poor OS (HR 1.50; 95\% CI 1.19-1.88; $P=0.001$; Fig. 2). Moreover, significant heterogeneity across studies was observed $\left(I^{2}\right.$ 61.5\%; $P<0.001)$. Sensitivity analysis revealed that the conclusion was not altered after sequential exclusion of individual studies (Additional file 1). The results of subgroup analyses indicated the results in most subsets were consistent with overall analysis, whereas pretreatment thrombocytosis did not affect the OS when pooled studies published in 2010 or after, studies conducted in Eastern countries, studies with sample size $<100$, mean patients age $\geq 50.0$ years, platelet cutoff value $<300$, pooled crude results, and studies with lower quality (Table 2). The results of the publication bias analysis are presented in Additional file 2, and the Egger $(P=0.916)$ and Begg $(P=0.537)$ test results showed no significant publication bias for OS.

\section{Progression-free survival}

The prognostic value of pretreatment thrombocytosis on PFS was available in eight studies. Thrombocytosis before treatment was associated with a poor PFS (HR 1.33; 95\% CI 1.07-1.64; $P=0.010$; Fig. 3), and non-significant heterogeneity was also observed $\left(I^{2} 23.8 \% ; P=0.232\right)$. The pooled results varied due to marginal $95 \%$ CI values (Additional file 1). Subgroup analyses indicated that pretreatment thrombocytosis was associated with a poor PFS in studies published in 2010 or after, studies conducted in Western countries, in sample sizes $\geq 100$, in studies that did not report a mean age, platelet cutoff $\geq$ 300 , pooled adjusted results, and studies with high quality (Table 2). There was no significant publication bias for PFS (Egger and Begg $P$ values 0.259 and 0.348, respectively; Additional file 2).

\section{Recurrence-free survival}

The prognostic value of pretreatment thrombocytosis on RFS was available in five studies. The summary HR indicated that pretreatment thrombocytosis was associated with a poor RFS (HR 1.66; 95\% CI 1.20-2.28; $P=0.002$; Fig. 4) and nonsignificant heterogeneity was observed across the included studies $\left(I^{2} 18.0 \% ; P=0.300\right)$. The results of sensitivity analysis indicated that the pooled result was stable after excluding any single study (Additional file 1). Subgroup analysis indicated that this significant association was observed mostly in subsets, whereas pretreatment thrombocytosis could not affect RFS when pooled studies published before 2010, studies conducted in Western countries, studies that did not report a mean age, in patients who received other treatment strategies, platelet cutoff $\geq$ 
Table 2 Subgroup analyses for OS, PFS, and RFS

\begin{tabular}{|c|c|c|c|c|c|c|c|}
\hline Outcomes & Factors & Groups & $\mathrm{HR}$ and $95 \% \mathrm{Cl}$ & $P$ value & $\begin{array}{l}\text { Heterogeneity } \\
\text { (\%) }\end{array}$ & $\begin{array}{l}P \text { value for } \\
\text { heterogeneity }\end{array}$ & $\begin{array}{l}P \text { value between } \\
\text { subgroups }\end{array}$ \\
\hline \multirow[t]{17}{*}{$\overline{O S}$} & \multirow[t]{2}{*}{ Publication year } & Before 2010 & $1.85(1.43-2.40)$ & $\begin{array}{l}< \\
0.001\end{array}$ & 22.3 & 0.266 & 0.039 \\
\hline & & 2010 or after & $1.29(0.94-1.77)$ & 0.111 & 67.6 & 0.001 & \\
\hline & \multirow[t]{2}{*}{ Country } & Eastern & $1.15(0.77-1.72)$ & 0.485 & 74.2 & $<0.001$ & 0.013 \\
\hline & & Western & $1.78(1.47-2.15)$ & $<0.001$ & 4.2 & 0.400 & \\
\hline & \multirow[t]{2}{*}{ Sample size } & $\geq 100$ & $1.56(1.28-1.89)$ & $<0.001$ & 44.6 & 0.036 & 0.029 \\
\hline & & $<100$ & $1.64(0.31-8.64)$ & 0.562 & 85.0 & 0.001 & \\
\hline & \multirow[t]{3}{*}{ Mean age (years) } & $\geq 50.0$ & $1.16(0.63-2.13)$ & 0.638 & 83.7 & $<0.001$ & 0.055 \\
\hline & & $<50.0$ & $1.67(1.34-2.08)$ & $<0.001$ & 17.1 & 0.295 & \\
\hline & & Not reported & $1.68(1.26-2.24)$ & $<0.001$ & 0.0 & 0.425 & \\
\hline & \multirow[t]{2}{*}{$\begin{array}{l}\text { Treatment } \\
\text { strategy }\end{array}$} & $\begin{array}{l}\text { Surgery } \\
\text { alone }\end{array}$ & $1.64(1.05-2.57)$ & 0.031 & 66.0 & 0.012 & 0.774 \\
\hline & & Other & $1.41(1.06-1.89)$ & 0.020 & 65.9 & 0.002 & \\
\hline & \multirow[t]{2}{*}{ Cutoff value } & $\geq 300$ & $1.53(1.14-2.05)$ & 0.004 & 67.7 & $<0.001$ & 0.851 \\
\hline & & $<300$ & $1.43(0.97-2.11)$ & 0.069 & 46.4 & 0.113 & \\
\hline & \multirow[t]{2}{*}{ Adjusted } & Yes & $1.68(1.38-2.05)$ & $<0.001$ & 0.0 & 0.748 & 0.149 \\
\hline & & No & $1.39(0.98-1.96)$ & 0.063 & 70.7 & $<0.001$ & \\
\hline & \multirow[t]{2}{*}{ Study quality } & High & $1.67(1.37-2.03)$ & $<0.001$ & 0.0 & 0.917 & 0.174 \\
\hline & & Low & $1.44(1.00-2.07)$ & 0.052 & 71.6 & $<0.001$ & \\
\hline \multirow[t]{18}{*}{ PFS } & \multirow[t]{2}{*}{ Publication year } & Before 2010 & $1.54(0.80-2.96)$ & 0.196 & - & - & 0.699 \\
\hline & & 2010 or after & $1.29(1.02-1.64)$ & 0.036 & 32.4 & 0.170 & \\
\hline & \multirow[t]{2}{*}{ Country } & Eastern & $1.18(0.90-1.55)$ & 0.241 & 33.7 & 0.183 & 0.115 \\
\hline & & Western & $1.71(1.22-2.39)$ & 0.002 & 0.0 & 0.790 & \\
\hline & \multirow[t]{2}{*}{ Sample size } & $\geq 100$ & $1.39(1.16-1.67)$ & $<0.001$ & 0.0 & 0.442 & 0.235 \\
\hline & & $<100$ & $1.08(0.22-5.24)$ & 0.919 & 69.2 & 0.071 & \\
\hline & \multirow[t]{3}{*}{ Mean age (years) } & $\geq 50.0$ & $1.18(0.72-1.94)$ & 0.508 & 63.8 & 0.063 & 0.215 \\
\hline & & $<50.0$ & $0.66(0.27-1.62)$ & 0.365 & - & - & \\
\hline & & Not reported & $1.48(1.16-1.89)$ & 0.001 & 0.0 & 0.756 & \\
\hline & \multirow[t]{2}{*}{$\begin{array}{l}\text { Treatment } \\
\text { strategy }\end{array}$} & $\begin{array}{l}\text { Surgery } \\
\text { alone }\end{array}$ & $1.31(0.93-1.84)$ & 0.127 & 0.0 & 0.797 & 0.794 \\
\hline & & Other & $1.28(0.92-1.78)$ & 0.144 & 49.9 & 0.076 & \\
\hline & \multirow[t]{3}{*}{ Cutoff value } & $\geq 300$ & $1.42(1.12-1.80)$ & 0.004 & 19.8 & 0.284 & 0.228 \\
\hline & & $<300$ & $1.02(0.63-1.65)$ & 0.936 & 23.6 & 0.253 & \\
\hline & & Not reported & $\begin{array}{l}2.72(0.61- \\
12.10)\end{array}$ & 0.189 & - & - & \\
\hline & \multirow[t]{2}{*}{ Adjusted } & Yes & $1.45(1.11-1.88)$ & 0.006 & 0.0 & 0.547 & 0.539 \\
\hline & & No & $1.23(0.86-1.75)$ & 0.266 & 43.9 & 0.113 & \\
\hline & \multirow[t]{2}{*}{ Study quality } & High & $1.52(1.24-1.88)$ & $<0.001$ & 0.0 & 0.789 & 0.046 \\
\hline & & Low & $0.96(0.57-1.60)$ & 0.867 & 37.8 & 0.185 & \\
\hline \multirow[t]{5}{*}{ RFS } & \multirow[t]{2}{*}{ Publication year } & Before 2010 & $\begin{array}{l}8.50(0.78- \\
92.40)\end{array}$ & 0.079 & - & - & 0.173 \\
\hline & & 2010 or after & $1.60(1.22-2.10)$ & 0.001 & 0.7 & 0.388 & \\
\hline & \multirow[t]{2}{*}{ Country } & Eastern & $1.71(1.24-2.34)$ & 0.001 & 0.0 & 0.587 & 0.624 \\
\hline & & Western & $1.98(0.75-5.24)$ & 0.167 & 53.9 & 0.114 & \\
\hline & Sample size & $\geq 100$ & $1.55(1.17-2.04)$ & 0.002 & 0.0 & 0.369 & 0.140 \\
\hline
\end{tabular}


Table 2 Subgroup analyses for OS, PFS, and RFS (Continued)

\begin{tabular}{|c|c|c|c|c|c|c|c|}
\hline Outcomes & Factors & Groups & $\mathrm{HR}$ and $95 \% \mathrm{Cl}$ & $P$ value & $\begin{array}{l}\text { Heterogeneity } \\
(\%)\end{array}$ & $\begin{array}{l}P \text { value for } \\
\text { heterogeneity }\end{array}$ & $\begin{array}{l}P \text { value between } \\
\text { subgroups }\end{array}$ \\
\hline & & $<100$ & $3.35(1.25-9.00)$ & 0.017 & 0.0 & 0.400 & \\
\hline & \multirow[t]{2}{*}{ Mean age (years) } & $<50.0$ & $1.51(1.04-2.18)$ & 0.029 & 17.7 & 0.297 & 0.308 \\
\hline & & Not reported & $2.52(0.82-7.71)$ & 0.105 & 29.0 & 0.235 & \\
\hline & \multirow[t]{2}{*}{$\begin{array}{l}\text { Treatment } \\
\text { strategy }\end{array}$} & $\begin{array}{l}\text { Surgery } \\
\text { alone }\end{array}$ & $1.75(1.28-2.40)$ & $<0.001$ & 0.3 & 0.367 & 0.399 \\
\hline & & Other & $1.54(0.64-3.73)$ & 0.334 & 53.7 & 0.141 & \\
\hline & \multirow[t]{2}{*}{ Cutoff value } & $\geq 300$ & $2.52(0.82-7.71)$ & 0.105 & 29.0 & 0.235 & 0.308 \\
\hline & & $<300$ & $1.51(1.04-2.18)$ & 0.029 & 17.7 & 0.297 & \\
\hline & \multirow[t]{2}{*}{ Adjusted } & Yes & $2.40(0.59-9.69)$ & 0.221 & 45.3 & 0.176 & 0.872 \\
\hline & & No & $1.63(1.00-2.66)$ & 0.048 & 33.8 & 0.221 & \\
\hline & \multirow[t]{2}{*}{ Study quality } & High & $1.60(1.09-2.36)$ & 0.017 & - & - & 0.886 \\
\hline & & Low & $1.78(1.04-3.05)$ & 0.034 & 38.2 & 0.183 & \\
\hline
\end{tabular}

300 , and pooled adjusted results (Table 2). No evidence of publication bias was observed (Egger and Begg $P$ values 0.235 and 0.221 , respectively; Additional file 2).

\section{Discussion}

The current meta-analysis performed a comprehensive search for published articles and explored the prognostic role of pretreatment thrombocytosis on survival outcomes in patients with cervical cancer. This quantitative study involved 6521 patients from 19 retrospective studies with a wide range of patient characteristics. The results of this study indicated that thrombocytosis before treatment was associated with poor OS, PFS, and RFS. Moreover, the association between pretreatment thrombocytosis and OS is differing according to publication year, country, and sample size, and the association between pretreatment thrombocytosis and PFS could be affected by study quality. The findings of this study indicated pretreatment thrombocytosis was a clinically useful marker to facilitate risk stratification and guide postoperative treatment management.

Numerous systematic review and meta-analysis have already evaluated the role of pretreatment thrombocytosis on prognosis in patients with cancer at various sites. They point out pretreatment thrombocytosis was associated with poor survival for gastric cancer [46, 47], colorectal cancer [48-53], hepatocellular carcinoma [54-56], renal cell carcinoma $[57,58]$, and endometrial carcinoma [59]. Moreover, a previous meta-analysis illustrated the prognostic value of pretreatment thrombocytosis in patients with gynecologic malignancies, in which patients with thrombocytosis at diagnosis had an increased risk

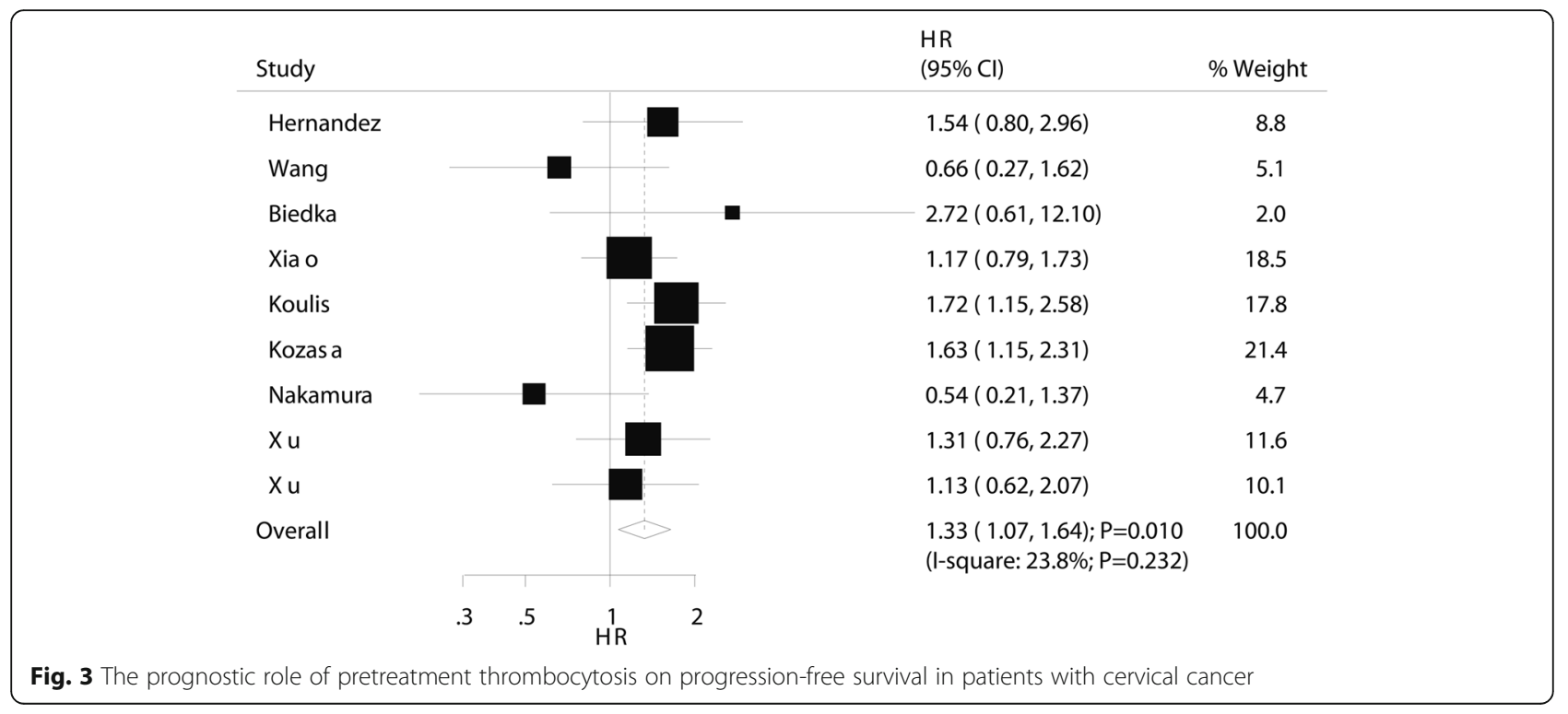




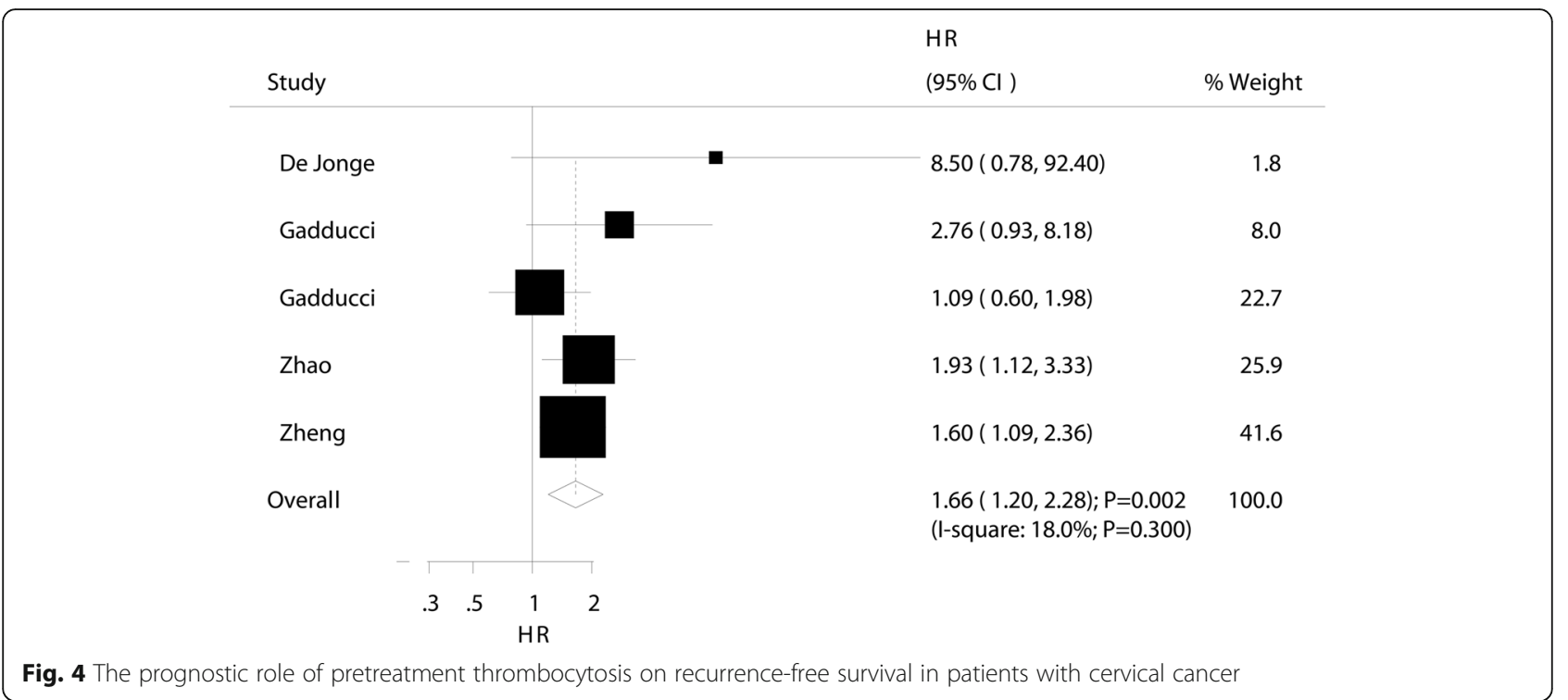

of mortality and patients with gynecologic malignancies had a worse prognosis [60]. The study included only 7 studies that recruited patients with cervical cancer and stratified analysis was not conducted. Another important study found pretreatment thrombocytosis to be an independent prognosis factor of OS and RFS in patients with cervical cancer, whereas it was not associated with PFS [61]. However, several important studies were not included in that study. Moreover, stratified analyses of PFS and RFS were not conducted. Therefore, the current meta-analysis was conducted to identify any new additional information regarding the prognostic role of pretreatment thrombocytosis for patients with cervical cancer.

The summary result of this study found that pretreatment thrombocytosis was associated with a poor OS. Most of the included studies reported similar or non-significant trends for OS and several included studies reported inconsistent results. Wang et al. did not observe a significant association between thrombocytosis before neoadjuvant chemotherapy and OS in patients with early-stage cervical cancer [41]. Li et al. found that thrombocytosis before treatment was associated with an increased risk of mortality, although this association was not statistically significant in Cox regression analysis [36]. Nakamura et al. reported pretreatment thrombocytosis to be associated with improved OS, which was not consistent with the results of previous studies [38]. The potential explanations for this include differences in patient characteristics, treatment strategies, and platelet count cutoff values [29]. Moreover, tumors may induce platelet activation and aggregation in the vasculature, which could cause the expression of angiogenesis regulatory factors [62].

In the present study, pretreatment thrombocytosis was associated with a poor PFS in patients with cervical cancer and only two of the included studies reported consistent results. Koulis et al. indicated that pretreatment and on-treatment anemia were correlated with worse survival. Moreover, an elevated platelet count was associated with poor OS in patients with various stages [34]. Kozasa et al. reported pretreatment thrombocytosis and elevated platelet-lymphocyte ratio to be independent factors in patients with cervical cancer, and the prognostic role of platelet counts was more sensitive than that of the platelet-lymphocyte ratio [35]. The potential explanation for this finding may be that tumor treatment could promote thrombopoiesis and stimulate cytokines or growth factors, their receptors, or their downstream effectors, which could affect the therapeutic effects in patients with cervical cancer.

The summary results indicated that pretreatment thrombocytosis was correlated with poor RFS in patients with cervical cancer and two of the included studies reported the same conclusions. Zhao et al. included 220 early-stage cervical cancer patients, reporting that the presence of thrombocytosis before treatment was associated with an increased risk of recurrence [44]. Zheng et al. indicated an improved predictive performance with combined platelet count and FIGO, as well as additional risk stratification for operable cervical cancer patients [45]. One possible reason for this significant association could be interaction effects between thrombocytosis and tumor burden. Moreover, platelets might promote tumor vascular growth and platelet receptors and ligands could mediate tumor cell-platelet binding, which could change the biological behavior of the tumors [63, 64].

Subgroup analyses indicated that the prognostic role of pretreatment thrombocytosis on survival outcomes might be affected by the publication year, country, sample size, and study quality. The reason for this observation 
include (1) treatment strategies have developed rapidly, which could affect the disease prognosis; (2) disease diagnosis and incidence differ between Eastern and Western countries, and disease stage is significantly associated with disease prognosis; (3) sample size was correlated with the weight from the overall analysis and affected the 95\% CI of the effect estimate; and (4) study quality was significantly correlated with the evidence level which could have affected the reliability of the pooled results.

This study has several limitations: (1) all of the included studies were retrospective designs, which might induce potential confounders; (2) most of the studies provided crude results for the prognostic role of pretreatment thrombocytosis in patients with cervical cancer; (3) the studies included a wide range of patient characteristics and the heterogeneity among them was not fully interpreted, and further prospective study should be conducted to verify the findings of this study and evaluate the doseresponse curve for the association between platelet count before treatment and the prognosis of cervical cancer; (4) the cutoff value and definition of thrombocytosis were differing among included studies, which could affect the prognosis of cervical cancer; and (5) publication bias was inevitable due to the analysis based on published studies and the unavailability of unpublished data.

\section{Conclusion}

In conclusion, the pooled results of this study indicated that thrombocytosis before treatment was associated with a poor prognosis in patients with cervical cancer. The poor prognosis of thrombocytosis before treatment for OS was observed mainly in studies published before 2010, in Western countries, and in large sample sizes. Moreover, the prognostic role of pretreatment thrombocytosis on PFS might differ according to study quality. Further large prospective studies are needed to verify these results and stratified analyses based on patient characteristics should be conducted.

\section{Additional files}

Additional file 1: Figure S1. Sensitivity analysis for OS. Figure S2. Sensitivity analysis for PFS. Figure S3. Sensitivity analysis for RFS. (DOCX $438 \mathrm{~kb}$ )

Additional file 2: Figure S1. Funnel plot for OS. Figure S2. Funnel plot for PFS. Figure S3. Funnel plot for RFS. (DOCX 348 kb)

\section{Abbreviations}

Cis: Confidence intervals; HRs: Hazard ratios; OS: Overall survival; PFS: Progression-free survival; RFS: Recurrence-free survival; NOS: NewcastleOttawa Scale

Acknowledgements

Not applicable.

\section{Authors' contributions}

WC contributed to the protocol/project development, data collection or management, and manuscript writing/editing. XY contributed to the protocol/project development and data analysis. DC contributed to the data collection or management and data analysis. YZ contributed to the data collection or management and data analysis. NZ contributed to the data collection or management and data analysis. LX contributed to the protocol/ project development, data collection or management, and manuscript writing/editing. All authors read and approved the final manuscript.

\section{Funding}

None.

\section{Availability of data and materials}

All data generated or analyzed during this study are included in this published article and its supplementary information files.

\section{Ethics approval and consent to participate}

Not applicable.

\section{Consent for publication}

Not applicable.

\section{Competing interests}

The authors declare that they have no competing interests.

\section{Author details}

${ }^{1}$ College of Pharmacy, Zhejiang Pharmaceutical College, Ningbo 315100 , Zhejiang Province, China. ${ }^{2}$ Zhejiang Pharmaceutical College, No. 888, East Section of Yinxian Avenue, Higher Education Park, Ningbo 315100, Zhejiang Province, China.

Received: 7 March 2019 Accepted: 23 July 2019

Published online: 02 August 2019

References

1. Ferlay J, Soerjomataram I, Dikshit R, Eser S, Mathers C, Rebelo M, Parkin DM, Forman D, Bray F. Cancer incidence and mortality worldwide: sources, methods and major patterns in GLOBOCAN 2012. Int J Cancer. 2015;136: E359-86.

2. Jemal A, Bray F, Center MM, Ferlay J, Ward E, Forman D. Global cancer statistics. CA Cancer J Clin. 2011;61:69-90.

3. Min KJ, Lee JK, So KA, Kim MK. Association between passive smoking and the risk of cervical intraepithelial neoplasia 1 in Korean women. J Epidemiol. 2018;28:48-53.

4. Bond S. Large prospective study finds no association between oral contraceptive use and breast cancer but increased risk for cervical cancer. J Midwifery Womens Health. 2014;59:218-9.

5. Gonzalez D, Suarez EL, Ortiz AP. Cervical cancer screening and sexual risky behaviors among a population of hispanic origin. Womens Health Issues. 2015:25:254-61.

6. Roura E, Castellsague X, Pawlita M, Travier N, Waterboer T, Margall N, Bosch FX, de Sanjose S, Dillner J, Gram IT, et al. Smoking as a major risk factor for cervical cancer and pre-cancer: results from the EPIC cohort. Int J Cancer. 2014;135:453-66.

7. Landoni F, Maneo A, Colombo A, Placa F, Milani R, Perego P, Favini G, Ferri L, Mangioni C. Randomised study of radical surgery versus radiotherapy for stage Ib-lla cervical cancer. Lancet. 1997;350:535-40.

8. Waggoner SE. Cervical cancer. Lancet. 2003;361:2217-25.

9. Eifel PJ, Winter K, Morris M, Levenback C, Grigsby PW, Cooper J, Rotman M, Gershenson D, Mutch DG. Pelvic irradiation with concurrent chemotherapy versus pelvic and para-aortic irradiation for high-risk cervical cancer: an update of radiation therapy oncology group trial (RTOG) 90-01. J Clin Oncol. 2004;22:872-80.

10. Lin RJ, Afshar-Kharghan V, Schafer Al. Paraneoplastic thrombocytosis: the secrets of tumor self-promotion. Blood. 2014;124:184-7.

11. Buergy D, Wenz F, Groden C, Brockmann MA. Tumor-platelet interaction in solid tumors. Int J Cancer. 2012;130:2747-60.

12. Grivennikov SI, Greten FR, Karin M. Immunity, inflammation, and cancer. Cell. 2010;140:883-99. 
13. Ji Y, Sheng L, Du X, Qiu G, Su D. Elevated platelet count is a strong predictor of poor prognosis in stage I non-small cell lung cancer patients. Platelets. 2015;26:138-42.

14. Choi Y, Park B, Kim K, Jeong BC, Seo SI, Jeon SS, Choi HY, Lee JE, Lee HM. Erythrocyte sedimentation rate and anaemia are independent predictors of survival in patients with clear cell renal cell carcinoma. Br J Cancer. 2013; 108:387-94

15. Yesil A, Senates E, Bayoglu IV, Erdem ED, Demirtunc R, Kurdas Ovunc AO. Red cell distribution width: a novel marker of activity in inflammatory bowe disease. Gut Liver. 2011;5:460-7.

16. Stone RL, Nick AM, McNeish IA, Balkwill F, Han HD, Bottsford-Miller J, Rupairmoole R, Armaiz-Pena GN, Pecot CV, Coward J, et al. Paraneoplastic thrombocytosis in ovarian cancer. N Engl J Med. 2012;366:610-8.

17. Moher D, Liberati A, Tetzlaff J, Altman DG. Preferred reporting items for systematic reviews and meta-analyses: the PRISMA statement. PLoS Med. 2009;6:e1000097.

18. The Newcastle-Ottawa Scale (NOS) for assessing the quality of nonrandomised studies in meta-analysis http://www.ohri.ca/programs/ clinical_epidemiology/oxford.asp.

19. DerSimonian R, Laird N. Meta-analysis in clinical trials. Control Clin Trials. 1986;7:177-88.

20. Ades AE, Lu G, Higgins JP. The interpretation of random-effects metaanalysis in decision models. Med Decis Making. 2005;25:646-54.

21. Higgins JP, Thompson SG. Quantifying heterogeneity in a meta-analysis. Stat Med. 2002;21:1539-58.

22. Higgins JP, Thompson SG, Deeks JJ, Altman DG. Measuring inconsistency in meta-analyses. Bmj. 2003;327:557-60.

23. Tobias A. Assessing the influence of a single study in the meta-analysis estimate. Stata Tech Bull. 1999;47:15-7.

24. Deeks JJ, Altman DG, Bradburn MJ. Statistical methods for examining heterogeneity and combining results from several studies in meta-analysis. In: Egger M, Davey Smith G, Altman D, editors. Systematic reviews in health care: meta-analysis in context. 2nd ed. London: BMJ Books; 2001. p. 285-312.

25. Egger M, Davey Smith G, Schneider M, Minder C. Bias in meta-analysis detected by a simple, graphical test. BMJ. 1997;315:629-34.

26. Begg CB, Mazumdar M. Operating characteristics of a rank correlation test for publication bias. Biometrics. 1994;50:1088-101.

27. Biedka M, Makarewicz R, Kopczynska E, Marszalek A, Goralewska A, Kardymowicz $H$. Angiogenesis and lymphangiogenesis as prognostic factors after therapy in patients with cervical cancer. Contemp Oncol (Pozn). 2012;16:6-11.

28. De Jonge ET, Viljoen E, Lindeque BG, Amant F, Nesland JM, Holm R. The prognostic significance of p53, mdm2, c-erbB-2, cathepsin D, and thrombocytosis in stage IB cervical cancer treated by primary radical hysterectomy. Int J Gynecol Cancer. 1999;9:198-205.

29. Gadducci A, Cosio S, Zola P, Tisi G, Ferrero A, Piovano E, Cristofani R, Greco C, Sartori E. Pretreatment platelet and hemoglobin levels are neither predictive nor prognostic variables for patients with locally advanced cervical cancer treated with neoadjuvant chemotherapy and radical hysterectomy: a retrospective Italian study. Int J Gynecol Cancer. 2010:20:1399-404.

30. Gadducci A, Teti G, Barsotti C, Tana R, Fanucchi A, Orlandini C, Fabrini MG, Genazzani AR. Clinicopathological variables predictive of clinical outcome in patients with FIGO stage Ib2-IIb cervical cancer treated with cisplatin-based neoadjuvant chemotherapy followed by radical hysterectomy. Anticancer Res. 2010;30:201-8

31. Hernandez E, Donohue KA, Anderson LL, Heller PB, Stehman FB. The significance of thrombocytosis in patients with locally advanced cervical carcinoma: a Gynecologic Oncology Group study. Gynecol Oncol. 2000;78:137-42.

32. Hernandez E, Heller PB, Whitney C, Diana K, Delgado G. Thrombocytosis in surgically treated stage IB squamous cell cervical carcinoma (A Gynecologic Oncology Group study). Gynecol Oncol. 1994;55:328-32.

33. Hernandez E, Lavine M, Dunton CJ, Gracely E, Parker J. Poor prognosis associated with thrombocytosis in patients with cervical cancer. Cancer. 1992;69:2975-7.

34. Koulis TA, Kornaga EN, Banerjee R, Phan T, Ghatage P, Magliocco AM, LeesMiller SP, Doll CM. Anemia, leukocytosis and thrombocytosis as prognostic factors in patients with cervical cancer treated with radical chemoradiotherapy: a retrospective cohort study. Clin Transl Radiat Oncol. 2017:4:51-6.

35. Kozasa K, Mabuchi S, Komura N, Yokoi E, Hiromasa K, Sasano T, Kawano M, Matsumoto Y, Kobayashi E, Kimura T. Comparison of clinical utilities of the platelet count and platelet-lymphocyte ratio for predicting survival in patients with cervical cancer: a single institutional study and literature review. Oncotarget. 2017:8:55394-404.

36. Li X, Tan C, Zhang W, Zhou J, Wang Z, Wang S, Wang J, Wei L. Correlation Between Platelet and Hemoglobin Levels and Pathological Characteristics and Prognosis of Early-Stage Squamous Cervical Carcinoma. Med Sci Monit. 2015;21:3921-8

37. Lopes A, Daras V, Cross PA, Robertson G, Beynon G, Monaghan JM. Thrombocytosis as a prognostic factor in women with cervical cancer. Cancer. 1994;74:90-2.

38. Nakamura K, Nakayama K, Tatsumi N, Minamoto T, Ishibashi T, Ohnishi K, Yamashita H, Ono R, Sasamori H, Razia S, et al. Prognostic significance of pretreatment neutrophil-to-lymphocyte and platelet-to-lymphocyte ratios in nonsurgically treated uterine cervical carcinoma. Mol Clin Oncol. 2018;9:138-44.

39. Qiu MZ, Xu RH, Ruan DY, Li ZH, Luo HY, Teng KY, Wang ZQ, Li YH, Jiang WQ. Incidence of anemia, leukocytosis, and thrombocytosis in patients with solid tumors in China. Tumour Biol. 2010;31:633-41.

40. Rodriguez GC, Clarke-Pearson DL, Soper JT, Berchuck A, Synan I, Dodge RK The negative prognostic implications of thrombocytosis in women with stage IB cervical cancer. Obstet Gynecol. 1994:83:445-8.

41. Wang D, Wu M, Ren T, Wan XR, Feng FZ, Huang HF, Yang JX, Shen K, Xiang Y. Effects of pre-chemotherapy hemoglobin and platelet levels in patients with stage Ib2-Ilb cervical cancer treated with neoadjuvant chemotherapy followed by radical hysterectomy. Zhonghua Fu Chan Ke Za Zhi. 2012:47:577-81.

42. Xiao Y, Ren YK, Cheng HJ, Wang L, Luo SX. Modified Glasgow prognostic score is an independent prognostic factor in patients with cervical cancer undergoing chemoradiotherapy. Int J Clin Exp Pathol. 2015;8:5273-81.

43. Xu F, Li Y, Fan L, Ma J, Yu L, Yi H, Chen X, Wei W, Wu P, Liang L, et al. Preoperative SCC-Ag and thrombocytosis as predictive markers for pelvic lymphatic metastasis of squamous cervical cancer in early FIGO stage. J Cancer. 2018:9:1660-6.

44. Zhao K, Deng H, Qin Y, Liao W, Liang W. Prognostic significance of pretreatment plasma fibrinogen and platelet levels in patients with earlystage cervical cancer. Gynecol Obstet Invest. 2015;79:25-33.

45. Zheng RR, Huang XX, Jin C, Zhuang XX, Ye LC, Zheng FY, Lin F. Preoperative platelet count improves the prognostic prediction of the FIGO staging system for operable cervical cancer patients. Clin Chim Acta. 2017:473:198-203.

46. Yang $C$, Jiang $H$, Huang $S$, Hong $H$, Huang $X$, Wang $X$, Liao W, Wang $X$, Chen $X$, Jiang $L$. The prognostic role of pretreatment thrombocytosis in gastric cancer: a systematic review and meta-analysis. Medicine (Baltimore). 2018;97:e11763.

47. Wang YH, Kang JK, Zhi YF, Zhang Y, Wang ZQ, Zhou Q, Niu WY, Ma MJ. The pretreatment thrombocytosis as one of prognostic factors for gastric cancer: a systematic review and meta-analysis. Int J Surg. 2018;53:304-11.

48. Rao XD, Zhang H, Xu ZS, Cheng H, Shen W, Wang XP. Poor prognostic role of the pretreatment platelet counts in colorectal cancer: a meta-analysis. Medicine (Baltimore). 2018;97:e10831

49. Gu D, Szallasi A. Thrombocytosis portends adverse prognosis in colorectal cancer: a meta-analysis of 5,619 patients in 16 individual studies. Anticancer Res. 2017:37:4717-26.

50. Wang YH, Deng SJ, Yang YD, Yao N, Zhao JM, Min GT, Wang J, Xu TF, Zhao PY, Wang HP, Chen W. The pretreatment thrombocytosis may predict prognosis of patients with colorectal cancer: a systematic review and metaanalysis. Biomark Med. 2017;11:195-210.

51. Long Y, Wang T, Gao Q, Zhou C. Prognostic significance of pretreatment elevated platelet count in patients with colorectal cancer: a meta-analysis. Oncotarget. 2016;7:81849-61

52. He Y, Xia T, Bian H, Zhuo Z, Lu H, Wang Z. Pretreatment thrombocytosis predicts survival in colorectal cancer. Clin Res Hepatol Gastroenterol. 2016; 40:e59-60.

53. Zhao JM, Wang YH, Yao N, Wei KK, Jiang L, Hanif S, Wang ZX. Poor prognosis significance of pretreatment thrombocytosis in patients with colorectal cancer: a meta-analysis. Asian Pac J Cancer Prev. 2016;17:4295-300.

54. Zhang Z, Zhang Y, Wang W, Hua Y, Liu L, Shen S, Peng B. Thrombocytopenia and the outcomes of hepatectomy for hepatocellular carcinoma: a meta-analysis. J Surg Res. 2017;210:99-107.

55. Pang Q, Qu K, Zhang JY, Song SD, Liu SS, Tai MH, Liu HC, Liu C. The prognostic value of platelet count in patients with hepatocellular carcinoma: a systematic review and meta-analysis. Medicine (Baltimore). 2015;94:e1431.

56. Pang Q, Qu K, Bi JB, Liu SS, Zhang JY, Song SD, Lin T, Xu XS, Wan Y, Tai MH, et al. Thrombocytopenia for prediction of hepatocellular carcinoma 
recurrence: systematic review and meta-analysis. World J Gastroenterol. 2015;21:7895-906

57. Gu L, Li H, Gao Y, Ma X, Chen L, Li X, Zhang Y, Fan Y, Zhang X. The association of platelet count with clinicopathological significance and prognosis in renal cell carcinoma: a systematic review and meta-analysis. PLoS One. 2015;10:e0125538.

58. Men H, Liang C, Yu M. Thrombocytosis as a prognostic factor in patients with renal cell carcinoma: a meta-analysis of literature. I Cancer Res Ther. 2015;11:67-72

59. Nie D, Yang E, Li Z. Pretreatment thrombocytosis predict poor prognosis in patients with endometrial carcinoma: a systematic review and metaanalysis. BMC Cancer. 2019;19:73.

60. Yu M, Liu L, Zhang BL, Chen Q, Ma XL, Wu YK, Liang CS, Niu ZM, Qin X, Niu T. Pretreatment thrombocytosis as a prognostic factor in women with gynecologic malignancies: a meta-analysis. Asian Pac J Cancer Prev. 2012;13:6077-81.

61. Cheng J, Zeng Z, Ye Q, Zhang Y, Yan R, Liang C, Wang J, Li M, Yi M. The association of pretreatment thrombocytosis with prognosis and clinicopathological significance in cervical cancer: a systematic review and meta-analysis. Oncotarget. 2017;8:24327-36.

62. Sabrkhany S, Griffioen AW, Oude Egbrink MG. The role of blood platelets in tumor angiogenesis. Biochim Biophys Acta. 2011;1815:189-96.

63. Bambace NM, Holmes CE. The platelet contribution to cancer progression. J Thromb Haemost. 2011;9:237-49.

64. Jain S, Harris J, Ware J. Platelets: linking hemostasis and cancer. Arterioscler Thromb Vasc Biol. 2010;30:2362-7.

\section{Publisher's Note}

Springer Nature remains neutral with regard to jurisdictional claims in published maps and institutional affiliations.

Ready to submit your research? Choose BMC and benefit from:

- fast, convenient online submission

- thorough peer review by experienced researchers in your field

- rapid publication on acceptance

- support for research data, including large and complex data types

- gold Open Access which fosters wider collaboration and increased citations

- maximum visibility for your research: over $100 \mathrm{M}$ website views per year

At BMC, research is always in progress.

Learn more biomedcentral.com/submissions 